\title{
In-hospital and Six-Month Antithrombotic Therapy after Primary Percutaneous Coronary Intervention: Analysis of Acute Coronary Care Evaluation of Practice (ACCEPT) Registry
}

\author{
Fábio Salerno Rinaldi', Pedro Beraldo de Andrade², Mônica Vieira Athanazio de Andrade³, \\ Luiz Alberto Mattos ${ }^{4}$, Eliana Vieira Santucci ${ }^{5}$, Margaret Assad Cavalcante ${ }^{6}$, Carisi Anne Polanczyk \\ Luiz Eduardo Fonteles Ritt ${ }^{8}$, Paulo Márcio Sousa Nunes ${ }^{9}$, Silvio Giopatto ${ }^{10}$, on behalf of the \\ Investigators of the Acute Coronary Care Evaluation of Practice (ACCEPT) Registry
}

\begin{abstract}
Background: The ACCEPT registry was designed with the purpose of identifying the incorporation of evidence in the treatment of acute coronary syndrome. The objective of this analysis is to describe the antithrombotic therapy adopted in the treatment of patients undergoing primary percutaneous coronary intervention $(\mathrm{PCl})$ in centers participating in this national project. Methods: We evaluated the subgroup of patients undergoing primary $\mathrm{PCl}$, measuring variables related to demographic characteristics as well as the prescription of evidence-based interventions, focusing on in-hospital and 6-month antithrombotic therapy. Results: From August 2010 to December 2011, 588 patients with mean age of 61.8 \pm 12.3 years were studied, $75.2 \%$ were males and $24.1 \%$ had diabetes mellitus. The dual antiplatelet therapy most commonly given was the combination of acetylsalicylic acid (ASA) and clopidogrel. Unfractionated heparin and enoxaparin were the predominant anticoagulation therapy during and after the procedure, respectively. When compared to in-hospital prescription, a significant decrease in the rate of patients using ASA $(98.3 \%$ vs $93.9 \%$; $\mathrm{P}<$ $0.0001)$ and clopidogrel (95.4\% vs 67.7\%; P < 0.0001) was observed at the 6-month follow-up. Conclusions: In the ACCEPT registry, a high percentage of in hospital prescription of dual antiplatelet therapy was observed in patients undergoing primary $\mathrm{PCl}$, notably the combination of ASA and clopidogrel, with an inadvertent reduction of
\end{abstract}

\section{RESUMO}

Farmacoterapia Antitrombótica Intra-Hospitalar e aos Seis Meses após Intervenção Coronária Percutânea Primária: Análise do Registro da Prática Clínica em Síndrome Coronária Aguda (ACCEPT)

Introdução: O registro ACCEPT foi idealizado com o propósito de identificar a incorporação de evidências no tratamento da síndrome coronária aguda. O objetivo da presente análise é descrever a terapia antitrombótica adotada no tratamento de pacientes submetidos a intervenção coronária percutânea (ICP) primária em centros participantes desse projeto nacional. Métodos: Avaliamos o subgrupo de pacientes submetidos a ICP primária, aferindo as variáveis relacionadas às características demográficas bem como à prescrição de intervenções baseadas em evidências, com enfoque na farmacoterapia antitrombótica hospitalar e aos 6 meses de seguimento. Resultados: No período de agosto de 2010 a dezembro de 2011 foram avaliados 588 pacientes com média de idade de $61,8 \pm 12,3$ anos, $75,2 \%$ pertencentes ao sexo masculino e $24,1 \%$ portadores de diabetes melito. A terapia antiplaquetária dupla mais comumente administrada foi a associação ácido acetilsalicílico (AAS) e clopidogrel. Heparina não-fracionada e enoxaparina foram a terapêutica anticoagulante predominante durante e após o término do procedimento, respectivamente. Comparativamente à prescrição na fase intra-hospitalar, constatou-se, aos 6 meses de seguimento, queda significativa da taxa de

\footnotetext{
Interventionist cardiologist physician of Santa Casa de Marília. Marília, SP, Brazil.

Doctoral researcher. Intenvetionist cardiologist physician of Santa Casa de Marília. Marília, SP, Brazil.

${ }^{3}$ Cardiovascular Nursing specialist nurse of Santa Casa de Marília. Marília, SP, Brazil.

${ }^{4}$ Doctor. Physician of Instituto Dante Pazzanese de Cardiologia. São Paulo, SP, Brazil.

${ }^{5}$ Researcher at the Teaching and Research Institute of Hospital do Coração. São Paulo, SP, Brazil.

${ }^{6}$ Master. Cardiologist Physician of Hospital Regional Presidente Prudente. Presidente Prudente, SP, Brazil.

7 Doctor. Cardiologist physician of the Hospital de Clínicas de Porto Alegre. Porto Alegre, RS, Brazil.
}

\footnotetext{
${ }^{8}$ Doctor. Cardiologist physician of Instituto Cardiopulmonar de Salvador Salvador, BA, Brazil.

${ }^{9}$ Interventionist cardiologist physician of Hospital de Terapia Intensiva. Teresina, Pl, Brazil.

${ }^{10}$ Master. Interventionist cardiologist physician of Hospital Vera Cruz. Campinas, SP, Brazil.
}

Correspondence to: Pedro Beraldo de Andrade. Avenida Vicente Ferreira 828 - Marília, SP, Brazil - CEP 17515900

E-mail: pedroberaldo@gmail.com

Received on: 1/7/2013 • Accepted on: 3/4/2013 
clopidogrel at the 6-month follow-up, encouraging efforts to use evidence-based practices.

DESCRIPTORS: Myocardial infarction. Angioplasty. Registry. Platelet aggregation inhibitors.

$\mathrm{E}$ arly coronary reperfusion, whether mechanical or chemical, and antithrombotic therapy are important steps in the care of patients with acute myocardial infarction with ST-segment elevation (STEMI), known to be effective in reducing morbidity and mortality. Over the past 15 years, several randomized clinical trials, meta-analyses, and registries corroborated the positive impact of new reperfusion strategies and adjunctive drug therapy in this scenario, with subsequent incorporation into reviews of guidelines that direct cardiology practice. ${ }^{1-3}$

Observational analysis of the Can Rapid Risk Stratification of Unstable Angina Patients Suppress Adverse Outcomes with Early Implementation of the ACC/AHA Guidelines (CRUSADE) registry, encompassing 64,775 patients admitted to 350 institutions in the United States, found that every $10 \%$ increase in adherence to therapies with a class I degree of recommendation according to the guidelines brought a similar reduction of $10 \%$ in the in-hospital mortality risk. ${ }^{4}$ These findings can be translated to patients with STEMI, as shown in a Swedish registry involving 61,238 patients, which observed, over 12 years, that the increased adoption of evidence-based therapies promoted significant and sustained reduction in mortality. ${ }^{5}$

In Brazil, there is little information documenting clinical practice in patients with acute coronary syndrome at the national level. The Acute Coronary Care Evaluation of Practice (ACCEPT) registry was designed with the purpose of identifying the incorporation of evidence to the treatment of this disease. ${ }^{6}$ The goal of the present study is to describe the antithrombotic therapy used in the treatment of patients undergoing primary percutaneous coronary intervention $(\mathrm{PCl})$, during the in-hospital phase and at six months of follow-up, in the centers participating in this national project.

\section{METHODS}

The rationale, methodology, organization, and ACCEPT registry committees have all been previously detailed. 6,7 In summary, it is a prospective, voluntary, multicenter study, designed and managed by the Brazilian Society of Cardiology (Sociedade Brasileira de Cardiologia - SBC), logistically structured in the first pacientes em uso de AAS (98,3\% vs. 93,9\%; P < 0,0001) e clopidogrel (95,4\% vs. 67,7\%; P<0,0001). Conclusões: No registro ACCEPT, elevado porcentual de prescrição hospitalar de terapia antiplaquetária dupla foi observado em pacientes submetidos a ICP primária, notadamente da associação AAS e clopidogrel, com redução inadvertida do último aos 6 meses de seguimento, motivando esforços para adequação das práticas fundamentadas por evidências.

DESCRITORES: Infarto do miocárdio. Angioplastia. Registro. Inibidores da agregação de plaquetas.

semester of 2010, and with the start of patient data collection in August of the same year. A total of 2,608 patients enrolled until December 2011, corresponding to Phase I of the project, were analysed through completion of the dedicated electronic form (at admission, 30 days, and 180 days). For this purpose, 47 researching centers were organized, seeking to cover the greatest possible territorial extension, representing all regions of the Brazilian states, including hospitals with public assistance (Brazilian Unified Health System), health insurance companies, and private centers.

These centers were assembled using two criteria: an invitation was sent to institutions that had already been considered eligible, and an active search for new centers was conducted through the promotion of the opportunity to participate at the electronic portal of the SBC. The criteria for participation were evidence of available research ethics committee and the capacity to follow-up patients for up to one year, as well as the existence of patients who met the clinical scope of this registry.

All centers received training regarding the study protocol and electronic system, in person or by phone, supported by the coordination team. The quality control of study data was verified through several strategies, such as the use of a dedicated electronic form for collection of clinical variables, centralized verification of the collected variables, in-person monitoring of the five centers with larger numbers of recruited patients, and random selection of $20 \%$ of centers for in-person monitoring. The protocol was approved by the research ethics committee of the Hospital do Coração (São Paulo, SP, Brazil) and, subsequently, the study protocol was approved by the local committee of each participating center.

All patients signed the informed consent, and the study was performed in accordance with the principles of the current version of the Declaration of Helsinki, of the Good Clinical Practice Guidelines, and of Resolution 196/96 of the Brazilian National Health Council.

This study analysed STEMI patients undergoing primary $\mathrm{PCl}$, assessing the variables related to the demographic characteristics, as well as the prescription of evidence-based interventions, with a focus 
on antithrombotic drug therapy. Clinical outcomes analysed in this study were cardiovascular mortality, acute myocardial infarction, stroke, and severe bleeding. The occurrence of the above mentioned clinical outcomes was verified at admission and after 180 days. In accordance with the classification of the Bleeding Academic Research Consortium, ${ }^{8}$ severe bleeding was defined as type 3 (3a, bleeding with a decrease in hemoglobin $\geq 3 \mathrm{~g} / \mathrm{dL}$ and $<5 \mathrm{~g} / \mathrm{dL}$ or packed red blood cell transfusion; $3 \mathrm{~b}$, bleeding with a decrease in hemoglobin $\geq 5 \mathrm{~g} / \mathrm{dL}$, or cardiac tamponade or bleeding requiring surgical intervention, or bleeding requiring intravenous vasoactive drugs; and 3c, intracranial hemorrhage, or subcategories confirmed by autopsy, imaging assessment or lumbar puncture, or intraocular bleeding with vision impairment) or type 5 (5a, likely fatal bleeding; 5b definitive fatal bleeding).

This registry is owned by SBC, using its own financial resources dedicated to this purpose and its implementation. The Instituto de Ensino e Pesquisa do Hospital do Coração (IEP/HCor - São Paulo, SP, Brazil) was employed to operationalize this registry, under the coordination of SBC.

\section{Statistical Analysis}

Continuous variables were described as means and standard deviations, and categorical variables as absolute and relative frequencies. Proportions were compared between two independent groups using Fisher's exact test. The SAS (Statistical Analysis System - Cary, USA) software, version 9.3, was used for statistical analysis. p-values $<0.05$ (two-tailed) were considered statistically significant.

\section{RESULTS}

From August 2010 to December 2011 2,608 patients were evaluated, concerning Phase I of the ACCEPT

Table 1

Baseline clinical and demographic characteristics

\begin{tabular}{lc}
\hline Variables & $\mathbf{n}=\mathbf{5 8 8}$ \\
\hline Age, years (mean \pm SD) & $61.8 \pm 12.3$ \\
Male gender, n (\%) & $442(75.2)$ \\
Systemic arterial hypertension, n (\%) & $395(67.2)$ \\
Diabetes mellitus, n (\%) & $142(24.1)$ \\
Dyslipidaemia, n (\%) & $278(47.3)$ \\
Smoking, n (\%) & $185(31.5)$ \\
Obesity, n (\%) & $187(31.8)$ \\
Previous acute myocardial & $121(20.6)$ \\
infarction, $\mathrm{n}(\%)$ & \\
Previous stroke, n (\%) & $47(7.9)$ \\
Chronic renal failure, $\mathrm{n}(\%)$ & $17(2.9)$ \\
\hline
\end{tabular}

Table 2

Angiographic and procedural characteristics

\begin{tabular}{lc}
\hline Variables & $\mathbf{n}=\mathbf{5 8 8}$ \\
\hline Number of affected vessels, $\mathrm{n}(\%)$ & \\
One vessel & $296(50.3)$ \\
Two vessels & $172(29.3)$ \\
Three vessels & $111(18.9)$ \\
Non-obstructive atherosclerotic & $9(1.5)$ \\
disease & \\
Femoral access, n (\%) & $410(69.7)$ \\
Radial access, n (\%) & $178(30.3)$ \\
Stent implant, n (\%) & $562(95.6)$ \\
Drug-eluting & $126(22.4)$ \\
Bare-metal & $436(77.6)$ \\
Procedural success, n (\%) & $568(96.6)$ \\
\hline
\end{tabular}

registry, of whom 640 were submitted to primary $\mathrm{PCl}$. With a loss to follow-up at six months of $8.1 \%$ (52 cases), the final analysis consisted of 588 patients whose baseline clinical and demographic characteristics are shown in Table 1. The mean age of patients was 61.8 \pm 12.3 years, $75.2 \%$ were males, $24.1 \%$ had diabetes mellitus, and $20.6 \%$ had a history of acute myocardial infarction.

The percentage of normal epicardial flow (Thrombolysis in Myocardial Infarction [TIMI] 3) achieved at the end of the procedure with residual stenosis $<20 \%$ was high (>96\%). Stents were routinely used, with a predominance of bare-metal stents, whereas drug-eluting stents were used in $22.4 \%$ of the interventions. The approach was the predominantly femoral, corresponding to $69.7 \%$ of the cases (Table 2).

The most commonly administered dual antiplatelet therapy was the combination of acetylsalicylic acid (ASA) and clopidogrel. Unfractionated heparin and enoxaparin constituted the predominant anticoagulant therapy during and after the procedure, respectively (Table 3). Beta-blockers were prescribed to $76.7 \%$ of the patients, angiotensin-converting enzyme inhibitors or angiotensin receptor blockers to $68 \%$, and statins to $89.5 \%$. Compared to prescription at the in-hospital phase, it was observed that there was a significant decrease in the rate of patients using acetylsalicylic acid (98.3\% vs. 93.9\%; P < 0.0001) and clopidogrel $(95.4 \%$ vs. $67.7 \% ; \mathrm{P}<0.0001)$ at the six-month follow-up, with a small number proportion of patients using the new ADP $\mathrm{P}_{2} \mathrm{Y}_{12}$ receptor inhibitors, prasugrel $(0.7 \%$ vs. $0.3 \%$ ) or ticagrelor (1.2\% vs. $0.3 \%$ ) (Figure 1$)$.

Figure 2 illustrates the occurrence of adverse clinical outcomes at the end of 180 days, with a cumulative rate of combined events of $10.4 \%$, mainly due to new 


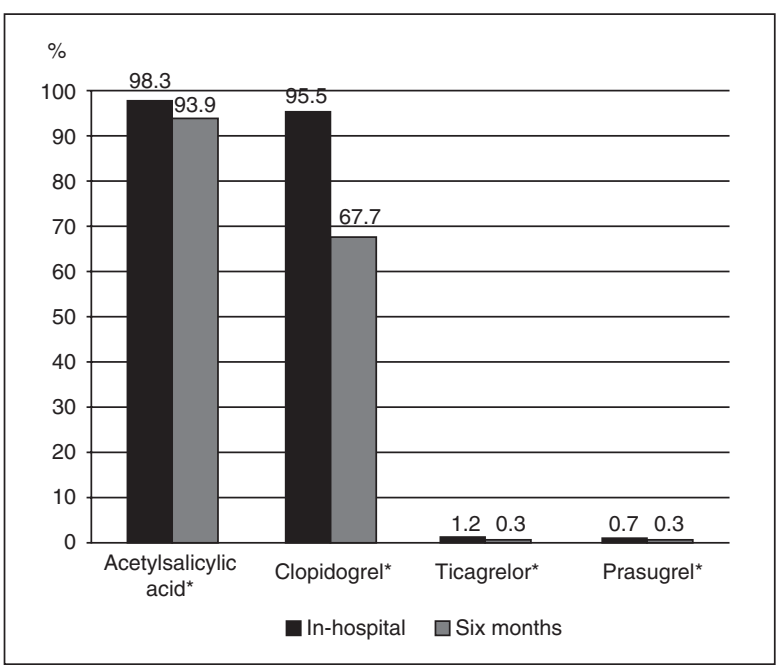

Figure 1 - Antiplatelet therapy in-hospital and at six months of followup $(* \mathrm{P}<0.0001)$

Table 3

In-hospital antithrombotic therapy

\begin{tabular}{lc}
\hline Variables & $\mathbf{n}=\mathbf{5 8 8}$ \\
\hline Acetylsalicylic acid, n (\%) & $578(98.3)$ \\
Clopidogrel, n (\%) & $561(95.4)$ \\
Prasugrel, n (\%) & $4(0.7)$ \\
Ticagrelor, n (\%) & $7(1.2)$ \\
Glycoprotein Ilb/Illa receptor & $114(19.4)$ \\
inhibitors, n (\%) & \\
Abciximab & $59(51.8)$ \\
Tirofiban & $55(48.2)$ \\
Intra-procedural unfractionated & $514(87.4)$ \\
heparin, $\mathrm{n}(\%)$ & $74(12.6)$ \\
Intra-procedural enoxaparin, $\mathrm{n}(\%)$ & $101(17.2)$ \\
Post-procedural unfractionated & \\
heparin, $\mathrm{n}(\%)$ & $377(64.1)$ \\
Post-procedural enoxaparin, $\mathrm{n}(\%)$ & $51(5.3)$ \\
Post-procedural fondaparinux, $\mathrm{n}(\%)$ &
\end{tabular}

cases of myocardial infarction in $6.8 \%$ of the population.

\section{DISCUSSION}

The main findings regarding antithrombotic drug therapy used in patients with acute myocardial infarction undergoing primary $\mathrm{PCl}$ in the first phase of the ACCEPT registry are the high rate of in-hospital prescription of dual antiplatelet therapy, primarily consisting of ASA and clopidogrel, restricted use of glycoprotein IIb/IIla receptor inhibitors, and the choice of unfractionated heparin as the standard anticoagulant agent during the procedure. As a caveat to the prescription

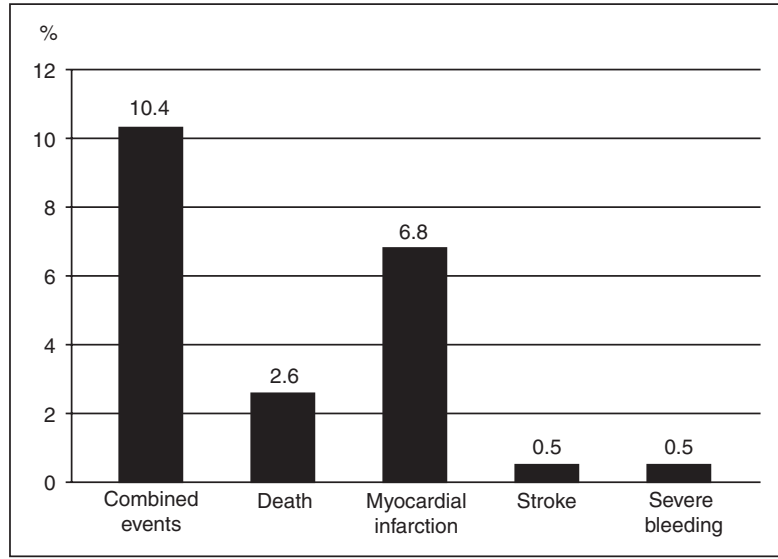

Figure 2 - Adverse clinical events at 6 months of follow-up.

of dual antiplatelet therapy at six months, a reduction in their use was observed, particularly ADP inhibitors, indicating the need for a better implementation of the current guidelines, whose recommendation is to extend therapy for a period of 12 months, given the positive impact on patient prognosis of greater adherence to established evidence. ${ }^{2,3}$

Clopidogrel was administered to over $95 \%$ of the assessed population, which may be explained by the extensive experience with the drug, the decrease in cost after its patent expired, and the available generic formulations, making it easily accessible even in the public health system, after its incorporation to the Line of Care in Acute Myocardial Infarction of the Emergency Care Network of the Brazilian Ministry of Health. Furthermore, the new $\mathrm{P}_{2} \mathrm{Y}_{12}$ inhibitors, prasugrel and ticagrelor, became commercially available in Brazil in late 2010 and mid-2011, respectively. Considering that the obtained data reflect patients included in the registry between August 2010 and December 2011, this explains the low number of individuals using these new agents.

In fact, prasugrel and ticagrelor are first-line antiplatelet drugs in the treatment of STEMI, since they have earlier action onset, and greater antiplatelet and anti-ischemic efficacy when compared to clopidogrel.9,10 In the Trial to Assess Improvement in Therapeutic Outcomes by Optimizing Platelet Inhibition - Thrombolysis in Myocardial Infarction 38 (TRITON-TIMI 38) study, prasugrel promoted a decrease in the primary composite outcome (cardiovascular death, myocardial infarction, and stroke) in patients undergoing primary $\mathrm{PCl}$, consistent with the findings of the main analysis, but without a significant increase in the risk of major bleeding unrelated to CABG. ${ }^{11}$ In turn, in the Platelet Inhibition and Patient Outcomes (PLATO) study, the use of ticagrelor determined a decrease in reinfarction, total mortality, and definitive stent thrombosis, analysed separately, at the expense of an increased rate of stroke, without increasing the risk of severe bleeding. ${ }^{12}$ 
Glycoprotein IIb/IIla receptor inhibitors, whose efficacy was demonstrated in studies performed before the routine use of dual antiplatelet therapy, showed a decline in their prescription, compared to previous publications. ${ }^{13,14}$ The consolidation of oral dual antiplatelet therapy, the constant search for the balance between anti-ischemic efficacy and safety, as well as the advent of ADP inhibitors with higher power justify this finding, whereas the use of parenteral agents are restricted to specific and rescue situations, such as large thrombotic burden, coronary flow disorders, and thrombotic complications.

As for the choice of anticoagulant administered during the procedure, considering the unavailability of new options, such as bivalirudin, unfractionated heparin remains the preferred agent. The former, not marketed in Brazil, showed a reduction of hospital mortality at 30 days, with maintenance of the benefit at three years, when compared to the association of unfractionated heparin and glycoprotein IIb/IIla inhibitors, a result attributed to the decrease in the occurrence of severe bleeding. ${ }^{15,16}$ The ACCEPT registry shows only a fraction of patients treated with enoxaparin during primary $\mathrm{PCl}$, a practice supported by the results of the Acute myocardial infarction treated with primary angioplasty and intravenous enoxaparin or unfractionated heparin to lower ischemic and bleeding events at short- and long-term follow-up (ATOLL) study. In this study, intravenous enoxaparin promoted a reduction of the main secondary composite outcome (death, recurrent acute coronary syndrome, or urgent revascularization), when compared to unfractionated heparin, with no difference in the primary composite outcome (death, acute myocardial infarction complication, procedural failure, or severe bleeding). ${ }^{17}$

Finally, the cardiovascular mortality rate of $2.6 \%$ at six months is close to rates obtained in randomized trials, characterized by patients with less severe clinical profile, thus differing from the published results of similar large international registries. ${ }^{18,19}$ However, comparative analysis of the ACCEPT registry with other registries should be performed with caution, given its limitations: it is restricted to the reality of the participating tertiary centers and their service profile; centers with less infrastructure and lacking a research ethics committee were excluded; patients were included in a voluntary and non-consecutive manner; and it had a limited number of patients when compared to similar international registries.

\section{CONCLUSIONS}

The ACCEPT registry shows a high percentage of in-hospital prescription of dual antiplatelet therapy to patients with acute myocardial infarction undergoing primary $\mathrm{PCl}$, notably the association of acetylsalicylic acid and clopidogrel, with an inadvertent decrease in the latter at six months of follow-up, which should encourage efforts to implement evidence-based practices. The decline in the use of glycoprotein IIb/IIla inhibitors follows a collective trend, supported by guidelines, and unfractionated heparin, despite the passage of time, remains the preferred anticoagulant agent in Brazil.

\section{CONFLICT OF INTERESTS}

The authors declare no conflicts of interests.

\section{ACKNOWLEDGMENTS}

The authors would like to thank Rodolfo Vieira and William Duraes, from - SBC, and Luis Duprat, from IEP/HCor.

\section{REFERENCES}

1. Piegas LS, Feitosa G, Mattos LA, Nicolau JC, Rossi Neto JM, Timerman A, et al. Sociedade Brasileira de Cardiologia. Diretriz da Sociedade Brasileira de Cardiologia sobre tratamento do infarto agudo do miocárdio com supradesnível do segmento ST. Arq Bras Cardiol. 2009;93(6 Supl 2):e179-e264.

2. Steg PG, James SK, Atar D, Badano LP, Lundqvist CB, Borger MA et al. ESC Guidelines for the management of acute myocardial infarction in patients presenting with ST-segment elevation. The task force on the management of ST-segment elevation acute myocardial infarction of the European Society of Cardiology (ESC). Eur Heart J. 2012;33(20):2569-619.

3. O'Gara PT, Kushner FG, Ascheim DD, Casey Jr DE, Chung MK, Lemos JA, et al. 2013 ACCF/AHA guideline for the management of ST-elevation myocardial infarction: a report of the American College of Cardiology Foundation/American Heart Association Task Force on Practice Guidelines. Circulation. 2013;127(4):e362-e425.

4. Peterson ED, Roe MT, Mulgund J, DeLong ER, Lytle BL, Brindis RG, et al. Association between hospital process performance and outcomes among patients with acute coronary syndromes. JAMA. 2006;295(16):1912-20.

5. Jernberg T, Johanson P, Held C, Svennblad B, Lindback J, Wallentin L. Association between adoption of evidenced-based treatment and survival for patients with ST-elevation myocardial infarction. JAMA. 2011;305(16):1677-84.

6. Mattos LAP. Racionalidade e métodos do Registro ACCEPT - Registro Brasileiro da Prática Clínica nas Síndromes Coronarianas Agudas da Sociedade Brasileira de Cardiologia. Arq Bras Cardiol. 2011;97(2):94-9.

7. Mattos LAP, Berwanger O, Santos ES, Reis HJL, Romano ER, Petriz JLF, et al. Desfechos clínicos aos 30 dias do Registro Brasileiro das Síndromes Coronárias Agudas (ACCEPT). Arq Bras Cardiol. 2013;100(1):6-13.

8. Mehran R, Rao SV, Bhatt DL, Gibson CM, Caixeta A, Eikelboom J, et al. Standardized bleeding definitions for cardiovascular clinical trials: a consensus report from the Bleeding Academic Research Consortium. Circulation. 2011;123(23):2736-47.

9. Wiviott SD, Braunwald E, McCabe CH, Montalescot G, Ruzyllo W, Gottlieb S, et al. Prasugrel versus clopidogrel in patients with acute coronary syndromes. N Engl J Med. 2007;357(20):2001-15.

10. Wallentin L, Becker RC, Budaj A, Cannon CP, Emanuelsson H, Held C, et al. Ticagrelor versus clopidogrel in patients with acute coronary syndromes. N Engl J Med. 2009;361(11):1045-57. 
11. Montalescot G, Wiviott SD, Braunwald E, Murphy SA, Gibson CM, McCabe $\mathrm{CH}$, et al. Prasugrel compared with clopidogrel in patients undergoing percutaneous coronary intervention for STelevation myocardial infarction (TRITONTIMI 38): double-blind, randomised controlled trial. Lancet. 2009;373 (9665):723-31.

12. Steg PG, James S, Harrington RA, Ardissino D, Becker RC, Cannon $\mathrm{CP}$, et al. Ticagrelor versus clopidogrel in patients with ST-elevation acute coronary syndromes intended for reperfusion with primary percutaneous coronary intervention: a Platelet Inhibition and Patient Outcomes (PLATO) subgroup analysis. Circulation. 2010;122(21):2131-41

13. Andrade PB, Tebet MA, Silva FSM, Andrade MVA, Mattos LA, Labrunie A. Utilização do acesso radial elimina a ocorrência de sangramento grave relacionado ao sítio de punção após intervenção coronária percutânea primária. Rev Bras Cardiol Invasiva. 2010;18(4):387-91.

14. Andrade PB, Tebet MA, Nogueira EF, Rinaldi FS, Esteves VC, Andrade MVA, et al. Impacto da transferência inter-hospitalar nos resultados da intervenção coronária percutânea primária. Rev Bras Cardiol Invasiva. 2012;20(4):361-6.

15. Stone GW, Witzenbichler B, Guagliumi G, Peruga JZ, Brodie BR, Dudek D, et al. Bivalirudin during primary $\mathrm{PCI}$ in acute myocardial infarction. N Engl J Med. 2008;358(21): 2218-30.

16. Stone GW, Witzenbichler B, Guagliumi G, Peruga JZ, Brodie BR, Dudek D, et al. Heparin plus a glycoprotein Ilb/IIla inhibitor vs. bivalirudin monotherapy and paclitaxeleluting stents vs. bare-metal stents in acute myocardial infarction (HORIZONS-AMI): final 3-year results from a multicentre, randomised controlled trial. Lancet. 2011;377(9784):2193-204.

17. Montalescot G, Zeymer U, Silvain J, Boulanger B, Cohen M, Goldstein $\mathrm{P}$, et al. Intravenous enoxaparin or unfractionated heparin in primary percutaneous coronary intervention for STelevation myocardial infarction: the international randomised open-label ATOLL trial. Lancet. 2011;378(9792):693-703.

18. Roe MT, Messenger JC, Weintraub WS, Cannon CP, Fonarow GC, Dai D, et al. Treatments, trends, and outcomes of acute myocardial infarction and percutaneous coronary intervention. Am Coll Cardiol. 2010;56(4):254-63.

19. Peterson ED, Dai D, DeLong ER, Brennan JM, Singh M, Rao SV, et al.; NCDR Registry Participants. Contemporary mortality risk prediction for percutaneous coronary intervention: results from 588,398 procedures in the National Cardiovascular Data Registry. J Am Coll Cardiol. 2010;55(18):1923-32.

\section{Appendix}

Participating research centers (city, state) and main investigator (number of patients included per center): Instituto Dante Pazzanese de Cardiologia (São Paulo, SP): Elisabete Silva dos Santos (318); Hospital de Clínicas Gaspar Vianna (Belém, PA): Helder José Lima Reis (154); Hospital do Coração (São Paulo, SP): Edson Renato Romano (151); Hospitais da Rede D'Or do Rio de Janeiro (Rio de Janeiro, RJ): João Luiz Fernandes Petriz (148); Hospital São Lucas (Aracaju, SE): Antônio Carlos Sobral Sousa (140); Hospital Vera Cruz (Belo Horizonte, MG): Fernando Neuesnchwander (137); Hospital Regional de Presidente Prudente (Presidente Prudente, SP): Margarete Assad Cavalcante (135); Hospital de Clínicas de Porto Alegre (Porto Alegre, RS): Carisi Polanczyk (120); Santa Casa de Marília (Marília, SP): Pedro Beraldo de Andrade (88); Instituto Cardiopulmonar (Salvador, BA): Luiz Eduardo Ritt (73); Hospital de Terapia Intensiva (Teresina, PI): Paulo Márcio Sousa Nunes (60); Hospital Vera Cruz (Campinas, SP): Silvio Giopatto (58); Instituto de Cardiologia de Santa Catarina (São José, SC): Ilnei Pereira Filho (57); Hospital São Vicente (Passo Fundo, RS): Hugo Vargas Filho (56); Hospital São Paulo (São Paulo, SP): Antônio Carlos C. Carvalho (52); Santa Casa de Votuporanga (Votuporanga, SP): Mauro Esteves Hernandes (49); Hospital Madre Teresa (Belo Horizonte, MG): Roberto Luiz Marino (44); Sociedade Hospital Angelina Caron (Campina Grande do Sul, PR): Dalton Bertolim Precoma (43); Hospital Lifecenter (Belo Horizonte, MG): Estevão Lanna Figueiredo (43); Hospital do Coração do Cariri (Barbalha, CE): Francisco Carleial Feijó de Sá (42); Hospital do Coração de Poços de Caldas (Poços de Caldas, MG): Frederico Toledo Campos Dall'Orto (42); Hospital Santa Izabel (Salvador, BA): Gilson Soares Feitosa Filho (37); Hospital Santa Paula (São Paulo, SP):
Otávio Celso Gebara (35); Hospital Regional do Mato Grosso do Sul (Campo Grande, MS): Christiano Pereira (35); Hospital Pró-Cardíaco (Rio de Janeiro, RJ): Luiz Antônio Almeida Campos (33); Hospital Universitário Francisca Mendes (Manaus, AM): Mariano Terrazas (31); Hospital Bandeirantes (São Paulo, SP): Hélio Castelo (30); Instituto Estadual de Cardiologia Aloysio de Castro (Rio de Janeiro, RJ): Roberto Bassan (30); Hospital do Coração do Brasil (Brasília, DF): Alberto Gomes Fonseca (29); Santa Casa de Porto Alegre (Porto Alegre, RS): Paulo Ernesto Leães (26); Hospital Santa Rita (Maringá, PR): Raul D'Aurea Mora Júnior (26); Centro Hospitalar Unimed (Joinville, SC): Rogério Carregoza Dantas (25); Hospital Sírio Libanês (São Paulo, SP): Roberto Kalil Filho (21); Hospital Universitário São Francisco (Bragança Paulista, SP): Murilo de Oliveira Antunes (20); Instituto de Moléstias Cardiovasculares (São José do Rio Preto, SP): Gilmar Valdir Greque (16); Hospital Estadual e Pronto-Socorro João Paulo II (Porto Velho, RO): Sérgio de Paulo Melo (15); Hospital Mãe de Deus (Porto Alegre, RS): Euler Manenti (11); Instituto de Cardiologia de Uruguaiana (Uruguaiana, RS): Sydnei Campodonico Filho (11): Real Hospital Português (Recife, PE): Sérgio Montenegro (9); Hospital Beneficência Portuguesa (São José do Rio Preto, SP): Gilmar Valdir Greque (7); Hospital da Cidade (Salvador, BA): Marcelo S. Teixeira (6); Hospital de Base da Sétima Região (Bauru, SP): Adriana F. Daher Berbel (5); Hospital Santa Izabel (Blumenau, SC): Sérgio L. Zimmermann (4); Instituto Nacional de Cardiologia (Rio de Janeiro, RJ): Marco Antônio de Mattos (4); Instituto do Coração do Triângulo Mineiro (Uberlândia, MG): Roberto Botelho (4); Hospital Prontocor (Rio de Janeiro, RJ): Paulo Henrique Godoy (3); and Instituto de Cardiologia do Distrito Federal (Brasília, DF): Núbia W. Vieira (2). 